\title{
Problem pierwszeństwa prawa Unii Europejskiej przed prawem krajowym - kilka uwag na tle orzecznictwa Trybunału Konstytucyjnego
}

\section{Uwagi wprowadzające}

Przystąpienie Polski do Unii Europejskiej spowodowało zmiany w wielu obszarach funkcjonowania państwa, w tym także w hierarchii źródeł prawa. Co warto podkreślić, z przystąpieniem do UE wiązało się nie tylko uzyskanie statusu państwa członkowskiego, ale przede wszystkim obowiązek natychmiastowego i pełnego przyjęcia dorobku prawnego UE do krajowego porządku prawnego².

Wśród podstawowych cech prawa UE w orzecznictwie Trybunału Sprawiedliwości $\mathrm{UE}^{3}$ oraz w literaturze poświęconej temu prawu ${ }^{4}$ wymienia się: nadrzędność, bezpośredni skutek i bezpośrednią stosowalność 5 . W razie kolizji między prawem UE a prawem krajowym bezwzględne pierwszeństwo należy przyznać temu pierwszemu, niezależnie od rodzaju aktu prawa krajowego (w założeniu dotyczy to także konstytucji państw członkowskich) ${ }^{6}$.

${ }^{1}$ Dr hab. Piotr Ruczkowski, profesor UJK, Uniwersytet Jana Kochanowskiego w Kielcach, Uniwersytet Pedagogiczny w Krakowie.

2 J. Sapieżko, S. Kardaś, Polska w Unii Europejskiej [w:] Unia Europejska, t. I, Geneza. System. Prawo, Warszawa 2007, s. 121.

${ }^{3}$ Wyrok TS z dnia 2 lutego 1962 r. w sprawie 26/62, NV Algemene Transport - en Expeditie Onderneming van Gend \& Loos v. Nederlandse Administratie der Belastingen, ECR 2001, s. 1; wyrok TS z dnia 15 lipca 1964 r. w sprawie 6/64, Flaminio Costa v. E.N.E.L., ECR 1964, s. 585; wyrok TS z dnia 9 marca 1978 r. w sprawie 106/77, Amministrazione delle Finanze dello Stato v. Simmenthal SpA, ECR 1978, s. 629; opinia TS 1/91 z dnia 14 grudnia 1991 r., ECR 1991, s. I-6079; opinia Służby Prawnej Rady z dnia 22 czerwca 2007 r., 11197/07, JUR 260.

${ }^{4}$ A. Wentkowska, Źródła prawa UE [w:] J. Barcik, A. Wentkowska, Prawo Unii Europejskiej z uwzględnieniem Traktatu z Lizbony, Warszawa 2008, s. 125 i n.; T.T. Koncewicz, Europejska Res Publica [w:] Europa urzędników, Z. Brodecki (red.), Warszawa 2009, s. 288 i n.; J. Sozański, Prawo Unii Europejskiej. Analiza krytyczna systemu i doktryny, Toruń 2014, s. 182 i n.

${ }^{5}$ A. Wentkowska, Źródła prawa UE..., s. 125 i n.

${ }^{6}$ Wyrok TS z dnia 17 grudnia 1970 r. w sprawie 11/70, Internationale Handelsgesellachaft GmbH v. Einfuhr und Vorratsstelle für Getreide und Futtermittel, ECR 1970, s. 1125. 
W tym przypadku podkreśla się, że mamy do czynienia z pierwszeństwem stosowania prawa UE, a nie $\mathrm{z}$ bezpośrednią i bezwzględną nieważnością prawa krajowego niezgodnego z prawem unijnym ${ }^{7}$. Ponieważ prawo unijne reguluje nie tylko prawa i obowiązki państw członkowskich, lecz także obywateli UE, w praktyce „pierwszeństwo stosowania” wywołuje podobny skutek jak uchylenie aktu normatywnego. $Z$ zasady pierwszeństwa wynika zakaz tworzenia prawa krajowego sprzecznego z prawem UE oraz zobowiązanie do uchylenia takiego prawa. Bezpośredni skutek oznacza możliwość powołania się przez osobę fizyczną lub prawną na konkretny przepis prawa UE w postępowaniu toczącym się przed organem państwowym (zarówno sądem, jak i organem administracyjnym). Z kolei bezpośrednia stosowalność przejawia się w braku obowiązku implementacji aktu prawnego UE do prawa krajowego, czyli możliwości rozstrzygania poszczególnych spraw bezpośrednio na podstawie aktów normatywnych UE.

Biorąc pod uwagę wspomniane cechy, w literaturze formułuje się pojęcia „tożsamość ponadnarodowa” czy też „otwarta państwowość". Generalnie chodzi tutaj o przekazanie kompetencji do tworzenia prawa zewnętrznego, które może ingerować w porządek prawny państwa, czy też obowiązującego bezpośrednio na poziomie danego państwa ${ }^{9}$. W praktyce mamy więc do czynienia ze zrzeczeniem się części suwerenności państwowej.

Celem niniejszego opracowania jest analiza poglądów Trybunału Konstytucyjnego na temat wyżej wymienionych cech prawa UE. W szczególności skoncentrowano się $\mathrm{w}$ nim na problematyce pierwszeństwa prawa unijnego przed prawem krajowym. W orzecznictwie i doktrynie prawa UE zasada ta raczej nie jest kwestionowana, natomiast poglądy Trybunału Konstytucyjnego nie są już tak jednoznaczne, zwłaszcza jeśli chodzi o relacje między prawem UE a Konstytucją $\mathrm{RP}^{10}$.

\section{Uwagi szczegółowe}

Szczegółowe rozważania na temat orzecznictwa Trybunału Konstytucyjnego warto poprzedzić przypomnieniem regulacji konstytucyjnych dotyczących źródeł prawa w odniesieniu do regulacji międzynarodowych i ponadnarodowych. Biorąc pod uwagę postanowienia Konstytucji RP, źródła prawa można podzielić na źródła powszechnie obowiązującego prawa

${ }^{7}$ R. Arnold, Tożsamość ponadnarodowa i narodowa w Traktacie z Lizbony [w:] Quo vadis Europo III?, E. Piontek, K. Karasiewicz (red.), Warszawa 2009, s. 55; K. Kowalik-Bańczyk, Tożsamość narodowa - dopuszczalny wyjątek od zasady prymatu? [w:] Prawo Unii Europejskiej a prawo konstytucyjne państw członkowskich, S. Dudzik, N. Półtorak (red.), Warszawa 2013, s. 32.

${ }^{8}$ R. Arnold, Tożsamość ponadnarodowa..., s. 54.

${ }^{9}$ Ibidem.

${ }^{10}$ Konstytucja Rzeczypospolitej Polskiej z dnia 2 kwietnia 1997 r., Dz.U. Nr 78, poz. 483 ze zm. 
oraz źródła prawa wewnętrznego. Podział ten według dominujących poglądów ma charakter dychotomiczny i zasadniczo został dokonany w oparciu o kryterium możliwego adresata aktu normatywnego oraz zakresu przedmiotowego regulacji. Do istotnych różnic pomiędzy tymi grupami źródeł prawa należy i to, że katalog źródeł powszechnie obowiązującego prawa został w Konstytucji wymieniony enumeratywnie, natomiast katalog źródeł prawa wewnętrznego ma charakter otwarty, zarówno jeśli chodzi o podmioty uprawnione do ich wydawania, jak i ich rodzaj. Otwarty charakter źródeł prawa wewnętrznego potwierdza orzecznictwo Trybunału Konstytucyjnego ${ }^{11}$.

Do źródeł powszechnie obowiązującego prawa ustawa zasadnicza zalicza: Konstytucję, ustawy, ratyfikowane umowy międzynarodowe, rozporządzenia z mocą ustawy, rozporządzenia oraz akty prawa miejscowego. Do źródeł powszechnie obowiązującego prawa należy również zaliczyć większość aktów normatywnych Unii Europejskiej.

Konstytucja RP explicite wśród źródeł prawa wewnętrznego wymienia uchwały Rady Ministrów oraz zarządzenia prezesa Rady Ministrów i ministrów. Przewiduje ponadto wydawanie zarządzeń przez Prezydenta RP oraz przewodniczących określonych w ustawach komitetów wchodzących w skład Rady Ministrów.

Z punktu widzenia problematyki będącej przedmiotem niniejszej pracy istotne znaczenia ma miejsce ustawy zasadniczej oraz prawa międzynarodowego i ponadnarodowego w konstytucyjnym systemie źródeł prawa. Konstytucja RP jest aktem normatywnym, który zawiera normy generalno-abstrakcyjne. Normatywny charakter Konstytucji nie budzi zastrzeżeń (z wyjątkiem preambuły, której niektórzy autorzy odmawiają charakteru normatywnego). W piśmiennictwie podkreślono, że „wypływają z niej normy prawne wyrażające nakazy i zakazy określonego postępowania adresowane do poszczególnych organów państwa"12. Nie ulega wątpliwości, że Konstytucja RP wiąże organy administracji publicznej zarówno w postępowaniu jurysdykcyjnym, jak i ogólnie w procesie administrowania ${ }^{13}$. Stosownie do art. 8 ust. 1 Konstytucji RP jest ona najwyższym prawem Rzeczypospolitej Polskiej. Przepisy Konstytucji stosuje się bezpośrednio, chy-

${ }^{11}$ Wyrok TK z dnia 1 grudnia 1998 r., K 21/98, OTK 1998, nr 7, poz. 116.

${ }^{12}$ P. Tuleja, Prawo konstytucyjne, Warszawa 1995, s. 16.

${ }^{13}$ Szerzej na temat bezpośredniego stosowania Konstytucji RP zob.: P. Ruczkowski, Zagadnienie bezpośredniego stosowania Konstytucji RP przez organy administracji publicznej i jej miejsce w systemie źródeł prawa [w:] Transformacja polska - oczekiwania i rzeczywistość, J. Dzwończyk, J. Kornaś (red.), „Studia i Prace Uniwersytetu Ekonomicznego w Krakowie" 2010, nr 12; P. Ruczkowski, Źródła prawa administracyjnego [w:] Prawo administracyjne. Część ogólna, ustrojowe prawo administracyjne, wybrane zagadnienia materialnego prawa administracyjnego, M. Zdyb, J. Stelmasiak (red.) Wolters Kluwer, Warszawa 2016 s. 41 i n.; L. Garlicki, Bezpośrednie stosowanie Konstytucji tezy referatu [w:] Konstytucja RP w praktyce, Warszawa 1999, s. 12 i n.; J. Zimmermann, Prawo administracyjne, Warszawa 2010, s. 56 i n. 
ba że stanowi ona inaczej (art. 8 ust. 2). W przepisie wymienionym wyżej wyrażono zasady nadrzędności ustawy zasadniczej oraz jej bezpośredniego stosowania.

Należy również zauważyć, że zasadniczo prawodawca krajowy jest również związany prawem międzynarodowym, przy czym należy mieć na względzie dyskusję na temat relacji pomiędzy prawem krajowym a prawem międzynarodowym, która stale toczy się w doktrynie i orzecznictwie. Obowiązek dotrzymywania zobowiązań międzynarodowych wynika z art. 27 Konwencji wiedeńskiej o prawie traktatów z dnia 23 maja 1969 r. ${ }^{14}$, zgodnie z którym strona umowy nie może powoływać się na postanowienia swego prawa wewnętrznego, by usprawiedliwić niewykonywanie przez siebie traktatów międzynarodowych (zasada pacta sunt servanda). Związanie to może wynikać także z art. 9 Konstytucji, zgodnie z którym Rzeczpospolita Polska przestrzega wiążącego ją prawa międzynarodowego. Przyznanie pierwszeństwa prawu międzynarodowemu można uzasadnić chociażby wymogiem dbania o prestiż i poważne traktowanie zobowiązań państwa w przestrzeni międzynarodowej. W zasadzie nie budzi wątpliwości pierwszeństwo przed ustawami takich umów międzynarodowych, których ratyfikacja jest uzależniona od uprzedniej zgody wyrażonej w ustawie ${ }^{15}$, co zresztą przewidziano explicite w Konstytucji RP (zob. art. 91 ust. 2).

Mając na względzie art. 9 oraz inne postanowienia Konstytucji RP, można postawić tezę o generalnym pierwszeństwie prawa międzynarodowego przed prawem krajowym, o czym była mowa wyżej. Takie stanowisko zajmuje przynajmniej część doktryny prawa konstytucyjnego ${ }^{16}$ oraz orzecznictwo sądowe ${ }^{17}$. Z kolei za twierdzeniem o pierwszeństwie ustawy przed umowami międzynarodowymi ratyfikowanymi w trybie zwykłym mogą przemawiać, po pierwsze, kolejność aktów normatywnych wymienionych w art. 87 ust. 1 Konstytucji RP (ratyfikowane umowy międzynarodowe

${ }^{14}$ Dz.U. z 1990 r. Nr 74, poz. 439 - załącznik.

${ }^{15}$ P. Tuleja, Źródła prawa [w:] Prawo konstytucyjne RP, P. Sarnecki (red.), Warszawa 2008, s. 58.

${ }^{16}$ B. Banaszak, Konstytucja Rzeczypospolitej Polskiej. Komentarz, Warszawa 2009, s. 459.

${ }^{17}$ W wyroku SN z dnia 18 maja 1980 r., I GR 58/70, przyjęto pierwszeństwo umowy międzynarodowej przed ustawą, cyt. za: L. Garlicki, B. Szepietowska, Miejsce prawa międzynarodowego $w$ systemie źródeł prawa wewnętrznego. Stan obecny i proponowane rozwiązania konstytucyjne, „Biuletyn. Ekspertyzy i Opinie Prawne” 1994, nr 4 (14), Kancelaria Sejmu. Biuro Studiów i Ekspertyz, Warszawa 1995, s. 9. Podobny pogląd został wyrażony w uchwale pełnego składu Izby Cywilnej SN z dnia 5 października 1974 r., III CZP 71/73, OSNC 1975, nr 5, poz. 72. Zdaniem Trybunału Konstytucyjnego Rzeczpospolita Polska przez ratyfikowanie umów międzynarodowych jest nimi związana, wobec czego powinny one być stosowane, w tym także przez sądy, i to na zasadzie proprio vigore, chyba że z treści i sposobu sformułowania umowy międzynarodowej wynika, że nie jest to akt samowykonalny (wyrok TK z dnia 7 stycznia 1992 r., K 8/91, OTK 1992, cz. 1, s. 84). 
zostały wymienione bezpośrednio po ustawach), po drugie, treść art. 91 ust. 2, w którym explicite pierwszeństwo przyznano jedynie umowom międzynarodowym ratyfikowanym za uprzednią zgodą wyrażoną w ustawie. A contario nie dotyczy to pozostałych rodzajów umów międzynarodowych. Z treści tego przepisu wynika, że zamiarem ustrojodawcy było danie pierwszeństwa tylko umowom ratyfikowanym w szczególnym trybie (za zgodą wyrażoną w ustawie).

Należy także zauważyć, że pierwszeństwo przed ustawami posiada również prawo stanowione przez organizację międzynarodową. Zgodnie bowiem z treścią art. 91 ust. 3 Konstytucji RP, jeżeli wynika to z ratyfikowanej przez RP umowy konstytuującej organizację międzynarodową, prawo przez nią stanowione jest stosowane bezpośrednio, mając pierwszeństwo w przypadku kolizji z ustawami. Dotyczy to w szczególności źródeł prawa wtórnego UE.

Do podstawowych źródeł prawa międzynarodowego zalicza się umowy międzynarodowe ${ }^{18}$. W oparciu o postanowienia Konstytucji RP umowy te możemy podzielić na ratyfikowane inieratyfikowane. Tylko umowy ratyfikowane zostały zaliczone do źródeł powszechnie obowiązującego prawa. A zatem pozostałe umowy, uwzględniając dychotomiczny podział źródeł prawa, mogą być co najwyżej zakwalifikowane do źródeł prawa wewnętrznego ${ }^{19}$.

Ratyfikuje i wypowiada umowy międzynarodowe Prezydent RP. Poprzez ratyfikację, czyli zatwierdzenie umowy przez właściwy organ, państwo zobowiązuje się do przestrzegania i stosowania umowy. Tryb ratyfikacji reguluje na ogół prawo krajowe. Biorąc pod uwagę tryb ratyfikacji, umowy międzynarodowe można podzielić na umowy międzynarodowe: 1) ratyfikowane $w$ trybie zwykłym oraz 2) ratyfikowane w trybie specjalnym. Ratyfikacja w trybie specjalnym dotyczy dwóch przypadków, po pierwsze, umów międzynarodowych, których ratyfikacja wymaga uprzedniej zgody wyrażonej w ustawie. Odnosi się to umów wymienionych w art. 89 ust. 1 Konstytucji, a więc umów dotyczących: 1) pokoju, sojuszy, układów politycznych lub układów wojskowych, 2) wolności, praw lub obowiązków obywatelskich określonych w Konstytucji, 3) członkostwa Rzeczypospolitej Polskiej w organizacji międzynarodowej, 4) znacznego obciążenia państwa pod względem finansowym, 5) spraw uregulowanych w ustawie lub w których Konstytucja wymaga ustawy, po drugie, umów, na podstawie których Polska może przekazać organizacji międzynarodowej lub organowi międzynarodowemu kompetencje organów władzy państwowej w niektó-

${ }^{18}$ W. Góralczyk, S. Sawicki, Prawo międzynarodowe publiczne, Warszawa 2009, s. 66; K. Ibsen, Völkerrecht, München 1999, s. 94 i n.; I. Seidl-Hohenveldern, T. Stein, Völkerrecht, Berlin-Bon-München 2000, s. 43 i n.; K. Doehring, Völkerrecht, C.F. Müller Verlag, Heidelberg 1999, s. 270 i n.

${ }^{19}$ L. Garlicki, Prawo międzynarodowe i prawo Unii Europejskiej [w:] System Prawa Administracyjnego, t. 2, Konstytucyjne podstawy funkcjonowania administracji publicznej, R. Hauser, Z. Niewiadomski, A. Wróbel (red.), Warszawa 2012, s. 86. 
rych sprawach (w istocie część suwerenności). Zgoda na ratyfikację takiej umowy może zostać wyrażona $\mathrm{w}$ drodze ustawy uchwalonej przez Sejm większością $2 / 3$ głosów w obecności co najmniej połowy ustawowej liczby posłów oraz przez Senat taką samą większością w obecności co najmniej połowy ustawowej liczby senatorów albo w drodze referendum ogólnokrajowego. Uchwałę w sprawie wyboru trybu ratyfikacji takiej umowy podejmuje Sejm bezwzględną większością głosów w obecności co najmniej połowy ustawowej liczby posłów (art. 90 ust. 1 i 2).

Jak wiemy, Konstytucja RP nie tylko zalicza ratyfikowane umowy międzynarodowe do źródeł powszechnie obowiązującego prawa, lecz przewiduje ponadto $\mathrm{w}$ art. 91 ust. 1, że tego typu umowa, po jej ogłoszeniu w „Dzienniku Ustaw”, stanowi część krajowego porządku prawnego i jest bezpośrednio stosowana, chyba że jej stosowanie jest uzależnione od wydania ustawy. $Z$ powyższego wynika, że bezpośrednio mogą być stosowane tylko niektóre umowy, tj. takie, które zawierają normy precyzyjne i w związku z tym ich stosowanie nie jest uzależnione od wydania ustawy.

Konstytucja RP nie wypowiada się wprost na temat prawa UE, co jest zrozumiałe, gdyż w chwili jej uchwalania nie byliśmy członkiem UE. Zawiera jednak regulacje, które znalazły się w Konstytucji RP z myślą o przyszłym członkostwie Polski w jej strukturach ${ }^{20}$. Dotyczy to zwłaszcza wspomnianego wyżej art. 91 ust. 3 Konstytucji RP, zgodnie z którym, jeżeli wynika to $\mathrm{z}$ ratyfikowanej przez RP umowy konstytuującej organizację międzynarodową, prawo przez nią stanowione jest stosowane bezpośrednio, mając pierwszeństwo w przypadku kolizji z ustawami, który można odnieść zwłaszcza do tzw. prawa pochodnego (wtórnego) UE. Z kolei do prawa pierwotnego (zawartego w Traktatach unijnych) można odnieść art. 91 ust. 1 i 2 Konstytucji RP. Mimo że te przepisy pozwoliły na ratyfikację Traktatu Akcesyjnego, to w literaturze zwraca się uwagę na sprzeczność niektórych przepisów ustawy zasadniczej z zasadami prawa UE - zwłaszcza art. 8 ust. 1, zawierającego zasadę nadrzędności Konstytucji RP, z zasadą pierwszeństwa prawa unijnego przed prawem krajowym (jak wspomniano wyżej, zasada ta - według poglądów doktryny i orzecznictwa unijnego obejmuje również konstytucje państw członkowskich) ${ }^{21}$.

Na system źródeł prawa UE składają się akty prawne o zróżnicowanym charakterze (generalno-abstrakcyjne, indywidualno-konkretne), dotyczące poszczególnych dziedzin integracji europejskiej. W doktrynie przeważa pogląd, że prawo UE tworzy odrębny (autonomiczny) porządek prawny, chociaż niekiedy tzw. prawo pierwotne (zobacz niżej) jest włączane do międzynarodowego prawa publicznego ${ }^{22}$. Pojęciem ściśle związanym ze źró-

${ }^{20}$ P. Winczorek, Konstytucja RP a prawo wspólnotowe, Państwo i Prawo 2004, z. 11, s. 3.

${ }^{21}$ Ibidem, s. 3 i n.

${ }^{22}$ S. Biernat, Prawo Unii Europejskiej a prawo państw członkowskich [w:] Prawo Unii Europejskiej. Zagadnienia systemowe, J. Barcz (red.), Warszawa 2003, s. 229; S. Biernat, 
dłami prawa UE jest acquis communautaire, które jest utożsamiane z całym dorobkiem prawnym UE, w tym z orzecznictwem TSUE ${ }^{23}$.

Stanowiące dorobek doktryny, orzecznictwa i częściowo ustawodawstwa unijnego zasady nadrzędności, bezpośredniego skutku i bezpośredniej stosowalności prawa UE można również wyprowadzić z art. 9, 90 i 91 Konstytucji RP. Nie dotyczy to jednak pierwszeństwa prawa UE przed Konstytucją RP. Jak wspomniano wyżej, pierwszeństwo prawa UE w tym przypadku potwierdza doktryna i orzecznictwo unijne. Co warto podkreślić, jedynie Konstytucja Republiki Cypryjskiej (art. 1a) ${ }^{24}$ przewiduje pierwszeństwo prawa UE przez ustawą zasadniczą, natomiast konstytucje pozostałych państw członkowskich co najwyżej wypowiadają się na temat pierwszeństwa prawa UE przed innymi źródłami prawa (ustawodawstwem zwykłym). A zatem kwestie relacji pomiędzy prawem unijnym a konstytucjami tych państw stały się przedmiotem orzecznictwa trybunałów konstytucyjnych i sądów powszechnych oraz przedmiotem rozważań doktryny, głównie konstytucjonalistów.

Pewien sprzeciw wobec zasady bezwzględnego pierwszeństwa prawa UE przed prawem krajowym wyrażały sądy konstytucyjne państw członkowskich UE.W tym zakresie należy zwrócić uwagę m.in. na orzeczenia niemieckiego Federalnego Trybunału Konstytucyjnego Solange-I-Beschluss z 29 maja 1974 r. ${ }^{25}$, Solange II z 22 października 1986 r. $^{26}$ oraz dotyczącego rynku bananów Bananenmarktordnung z 6 lipca 2000 r. ${ }^{27}$ Trybunał ten akceptuje zasady bezpośredniego skutku i bezpośredniej stosowalności prawa unijnego w obszarach regulacyjnych przypisanych UE, przy czym w zakresie praw podstawowych (i zasad ustrojowych) przewidział pierwszeństwo niemieckiej ustawy zasadniczej. W tym kontekście warto również zwrócić uwagę na orzeczenia Federalnego Trybunału Konstytucyjnego z dnia 12 października 1993 r. (Maastricht-Urteil) ${ }^{28}$ oraz z dnia 30 czerwca 2009 r. (Lisbon-Urteil) ${ }^{29}$.

M. Niedźwiedź, Prawo międzynarodowe a prawo unijne w świetle Konstytucji [w:] System Prawa Administracyjnego, t. 2..., s. 94.

${ }^{23}$ S. Biernat, Źródła prawa Unii Europejskiej [w:] Prawo Unii Europejskiej, J. Barcz (red.), Warszawa 2006, s. I-192; Z. Brodecki, Prawo integracji europejskiej, Warszawa 2001, s. 28-29; M. Muszyński, Unia Europejska jako reżim zamknięty prawa międzynarodowego [w:] M. Muszyński, D.E. Harnasiuk, M. Kozak, Unia Europejska - instytucje, polityki, prawo, Warszawa 2012, s. 69 i n.

${ }^{24}$ Konstytucja Republiki Cypryjskiej, http://biblioteka.sejm.gov.pl/wp-content/ uploads/2015/07/cypr-pol-31052012.pdf (dostęp: 8.08.2017).

${ }^{25}$ BVerfGE 37, 271.

${ }^{26}$ BVerfGE 73, 339.

${ }^{27}$ BVerfGE 102, 147.

${ }^{28} 2$ BvR 2134, 2159/92, BVerfGE 89, 155, http://www.servat.unibe.ch/dfr/bv089155. html (dostęp: 1.08.2017).

${ }^{29} 2$ BvE 2/08, BVerfGE 123, 267-437, http://www.bundesverfassungsgericht.de/ SharedDocs/Entscheidungen/DE/2009/06/es20090630_2bve000208.html (dostęp: 1.08.2017). 
W niniejszej pracy nie ma miejsca na szczegółową analizę orzecznictwa tego i innych trybunałów konstytucyjnych, natomiast należy przejść do przedstawienia i oceny poglądów polskiego Trybunału Konstytucyjnego ${ }^{30}$. Problem relacji prawa unijnego (przed wejściem w życie Traktatu z Lizbony nazywanego prawem wspólnotowym) znalazł swoje odzwierciedlenie niedługo po przystąpieniu Polski do UE, tj. w wyroku TK z dnia 27 kwietnia 2005 r. w sprawie europejskiego nakazu aresztowania ${ }^{31}$, w którym stwierdzono niezgodność norm prawa polskiego, wdrażających dyrektywę ramową o europejskim nakazie aresztowania, z ówczesnym art. 55 ust. 1 Konstytucji RP, co doprowadziło do zmian ustawy zasadniczej w tym zakresie.

Kolejny istotny wyrok TK, dotyczący m.in. zasady nadrzędności, zapadł w dniu 11 maja $2005 \mathrm{r}^{32} \mathrm{~W}$ tym przypadku Trybunał badał zgodność Traktatu o przystąpieniu Rzeczypospolitej Polskiej do Unii Europejskiej, podpisanego w dniu 16 kwietnia $2003 \mathrm{r}$. w Atenach ${ }^{33}$ (wraz z Traktatem o Unii Europejskiej i Traktatem ustanawiającym Wspólnotę Europejską, gdyż sprawy te połączono), w szczególności z art. 8 ust. 1 Konstytucji RP. W wyroku tym odnajdujemy kluczowe stanowisko tego organu. Przede wszystkim TK potwierdził, że „Art. 8 ust. 1 Konstytucji jednoznacznie gwarantuje postanowieniom Konstytucji status "najwyższego prawa Rzeczypospolitej Polskiej «”. Ponadto zwrócił uwagę na konieczność respektowania zobowiązań międzynarodowych, zaznaczając, że „Regulacji tej towarzyszy nakaz respektowania i przychylności wobec właściwie ukształtowanych oraz obowiązujących na terytorium Rzeczypospolitej Polskiej unormowań prawa międzynarodowego”. „Prawną konsekwencją art. 9 Konstytucji jest konstytucyjne założenie, iż na terytorium Rzeczypospolitej Polskiej, obok norm (przepisów) stanowionych przez krajowego legislatora, obowiązują uregulowania (przepisy) kreowane poza systemem krajowych (polskich) organów prawodawczych. Ustrojodawca konstytucyjny świadomie więc przyjął, że system prawa obowiązujący na terytorium Rzeczypospolitej mieć będzie charakter wieloskładnikowy. Obok aktów prawnych, stanowionych przez krajowe (polskie) organy prawodawcze, w Polsce obowiązują i są stosowane także akty prawa międzynarodowego". Trybunał zauważył również, że „Prawo wspólnotowe nie jest przy tym prawem w pełni zewnętrznym w stosunku do państwa polskiego. W części stanowiącej prawo traktato-

${ }^{30}$ P. Mikłaszewicz, Orzecznictwo Trybunału Konstytucyjnego w sprawach związanych z prawem Unii Europejskiej [w:] Europa urzędników, Z. Brodecki (red.), Warszawa 2009, s. 388 i n.

${ }^{31}$ Wyrok TK z dnia 27 kwietnia 2005 r., P 1/05, OTK-A 2005, nr 4, poz. 42.

${ }^{32}$ Wyrok TK z dnia 11 maja 2005 r., K 18/04, OTK-A 2005, nr 5, poz. 49; zob. J. Barcz, Glosa do wyroku Trybunału Konstytucyjnego z 11.5.2005 r. (zgodność Traktatu akcesyjnego $z$ Konstytucja RP) K 18/04, „Kwartalnik Prawa Publicznego” 2005, nr 4, s. 169-184; S. Biernat, Glosa do wyroku Trybunału Konstytucyjnego z 11.5.2005 r. (zgodność Traktatu akcesyjnego z Konstytucją RP) K 18/04, „Kwartalnik Prawa Publicznego” 2005, nr 4, s. 185-206.

${ }^{33}$ Dz.U. z 2004 r. Nr 90, poz. 864. 
we, powstaje ono przez akceptowanie traktatów zawartych przez wszystkie państwa członkowskie (w tym: Rzeczpospolitą Polską). W części zaś stanowiącej wspólnotowe prawo stanowione (pochodne), kreowane jest ono przy udziale przedstawicieli rządów państw członkowskich (w tym: Polski)”. Trybunał Konstytucyjny zwrócił uwagę również na to, że „Przekazanie kompetencji »w niektórych sprawach « rozumiane musi być zarówno jako zakaz przekazania ogółu kompetencji danego organu, przekazania kompetencji w całości spraw w danej dziedzinie, jak i jako zakaz przekazania kompetencji co do istoty spraw określających gestię danego organu władzy państwowej. Konieczne jest więc tak precyzyjne określenie dziedzin, jak i wskazanie zakresu kompetencji obejmowanych przekazaniem. (...) Działania, w wyniku których przeniesienie kompetencji podważałoby sens istnienia bądź funkcjonowania któregokolwiek z organów Rzeczypospolitej, pozostawałyby nadto w wyraźnej kolizji z art. 8 ust. 1 Konstytucji”. Szczególnie istotne są słowa TK dotyczące zachowania suwerenności państwowej. Trybunał Konstytucyjny stoi na stanowisku, że „ani art. 90 ust. 1, ani też art. 91 ust. 3 nie mogą stanowić podstawy do przekazania organizacji międzynarodowej (czy też jej organowi) upoważnienia do stanowienia aktów prawnych lub podejmowania decyzji, które byłyby sprzeczne z Konstytucją Rzeczypospolitej Polskiej. W szczególności wskazane tu unormowania nie mogą posłużyć do przekazania kompetencji w zakresie, który powodowałby, iż Rzeczpospolita Polska nie może funkcjonować jako państwo suwerenne i demokratyczne”.

Sprzeczność normy prawa UE z normą konstytucyjną w żadnym przypadku nie może prowadzić do uznania „nadrzędności normy wspólnotowej w relacji do normy konstytucyjnej”. Nie może też prowadzić do „utraty mocy obowiązującej normy konstytucyjnej i zastąpienia jej normą wspólnotową ani do ograniczenia zakresu stosowania tej normy do obszaru, który nie został objęty regulacją prawa wspólnotowego (...). W takiej sytuacji do polskiego ustawodawcy należałoby podjęcie decyzji albo o zmianie Konstytucji, albo o spowodowaniu zmian w regulacjach wspólnotowych, albo - ostatecznie - decyzji o wystąpieniu z Unii Europejskiej. Decyzję tę winien podjąć suweren, którym jest Naród Polski, lub organ władzy państwowej, który w zgodzie z Konstytucją może Naród reprezentować”. "Trybunał Konstytucyjny nie uznaje więc możliwości zakwestionowania mocy obowiązującej normy konstytucyjnej przez sam fakt wprowadzenia do systemu prawa europejskiego sprzecznej z nią regulacji wspólnotowej”.

W obszernie cytowanym wyżej wyroku TK zauważył, że zasada wykładni prawa krajowego przyjaznej prawu unijnemu, mimo że rozumiana szeroko, „W żadnej sytuacji nie może (...) prowadzić do rezultatów sprzecznych z wyraźnym brzmieniem norm konstytucyjnych i niemożliwych do uzgodnienia z minimum funkcji gwarancyjnych, realizowanych przez Konstytucję"34.

\footnotetext{
${ }^{34}$ Wyrok TK z dnia 11 maja 2005 r., K 18/04.
} 
Po nieudanej próbie przejścia do kolejnego etapu federalizacji UE poprzez przyjęcie tzw. Konstytucji dla Europy podjęto kolejne kroki zmierzające w tym kierunku - w postaci przyjęcia Traktatu z Lizbony, który zasadniczo wszedł w życie dnia 1 grudnia 2009 r. W Traktacie tym znalazły się przepisy, które były zawarte w projekcie Konstytucji dla Europy. Przepisy Traktatu z Lizbony, które - zdaniem wnioskodawców - szczególnie ingerowały w niezależność i suwerenność RP, podlegały ocenie TK w wyroku $\mathrm{z}$ dnia 24 listopada $2010 \mathrm{r}^{35} \mathrm{~W}$ wyroku tym TK, powołując się na Traktat Akcesyjny, zwrócił uwagę, że „istnieje ścisły związek zasady nadrzędności Konstytucji z suwerennością RP”. Zdaniem Trybunału „normy Konstytucji stanowią "wyraz suwerennej woli narodu« i dlatego »nie mogą utracić mocy obowiązującej bądź ulec zmianie przez sam fakt powstania nieusuwalnej sprzeczności pomiędzy określonymi przepisami (aktami wspólnotowymi a Konstytucją) «". Trybunał Konstytucyjny zwraca też uwagę, że „Pogląd o związku nadrzędności Konstytucji z zasadą suwerenności jest zbieżny ze stanowiskiem doktryny, w myśl którego zachowanie pierwszeństwa Konstytucji w warunkach integracji europejskiej musi być uznane za równoznaczne z zachowaniem suwerenności państwa" ${ }^{36}$. Podziela pogląd, że przystąpienie do UE wiąże się z częściowym ograniczeniem suwerenności państwowej. Dotyczy to jednak tylko kompetencji wyraźnie przekazanych UE. Przepisy Konstytucji RP umożliwiające przekazanie części kompetencji państwowych na rzecz UE, zdaniem TK, „nie mogą stanowić podstawy do przekazania organizacji międzynarodowej lub organowi międzynarodowemu upoważnienia do stanowienia aktów prawnych lub podejmowania decyzji, które byłyby sprzeczne z Konstytucją Rzeczypospolitej Polskiej".

Trybunał zauważa również, że „suwerenność Rzeczypospolitej i jej niepodległość, rozumiana jako odrębność bytu państwowego Polski w jej obecnych granicach, w warunkach członkostwa w Unii Europejskiej na zasadach określonych w Konstytucji, oznaczają potwierdzenie prymatu Narodu Polskiego do stanowienia o własnym losie. Normatywnym wyrazem tej zasady jest Konstytucja". W cytowanym wyroku TK wyraźnie przyjmuje, że „Z racji wynikającej z art. 8 ust. 1 Konstytucji nadrzędności mocy prawnej Konstytucja korzysta na terytorium Rzeczypospolitej Polskiej z pierwszeństwa obowiązywania i stosowania”. „Przekazanie kompetencji nie może naruszać postanowień Konstytucji, a w tym zasady nadrzędności Konstytucji w systemie źródeł prawa”. Zdaniem TK „Konstytucja pozostaje - z racji swej szczególnej mocy - "prawem najwyższym Rzeczypospolitej Polskiej« w stosunku do wszystkich wiążących Rzeczpospolitą Polską umów międzynarodowych. Dotyczy to także ratyfikowanych umów międzynarodo-

${ }^{35}$ Wyrok TK z dnia 24 listopada 2010 r., K 32/09, OTK-A 2010, nr 9, poz. 108.

${ }^{36}$ Zob. K. Wójtowicz, Suwerenność w procesie integracji europejskiej [w:] Spór o suwerenność, W. Wołpiuk (red.), Warszawa 2001, s. 174. 
wych o przekazaniu kompetencji »w niektórych sprawach «. Z racji wynikającej z art. 8 ust. 1 Konstytucji nadrzędności mocy prawnej korzysta ona na terytorium Rzeczypospolitej Polskiej z pierwszeństwa obowiązywania i stosowania. Trybunał Konstytucyjny stoi na stanowisku, że ani art. 90 ust. 1, ani też art. 91 ust. 3 nie mogą stanowić podstawy do przekazania organizacji międzynarodowej (czy też jej organowi) upoważnienia do stanowienia aktów prawnych lub podejmowania decyzji, które byłyby sprzeczne z Konstytucją Rzeczypospolitej Polskiej. W szczególności wskazane tu unormowania nie mogą posłużyć do przekazania kompetencji w zakresie, który powodowałby, iż Rzeczypospolita Polska nie może funkcjonować jako państwo suwerenne i demokratyczne. Zasadnicze znaczenie, z punktu widzenia suwerenności oraz ochrony innych wartości konstytucyjnych, ma ograniczenie możliwości przekazania kompetencji do "niektórych spraw « (a zatem bez naruszenia „rdzenia” uprawnień, umożliwiającego - w zgodzie z preambułą - suwerenne i demokratyczne stanowienie o losie Rzeczypospolitej)".

Jak widzimy, przytoczone obszerne fragmenty orzeczeń Trybunału Konstytucyjnego potwierdzają nadrzędność Konstytucji RP w systemie źródeł prawa również w odniesieniu do prawa UE. Przyjęta hierarchia źródeł prawa pełni funkcje gwarancyjną i stanowi element tożsamości narodowej i suwerenności państwowej.

Warto jeszcze zwrócić uwagę na wyrok TK z dnia 28 stycznia 2003 r. $^{37}$, w którym wyrażono pogląd o potrzebie wykorzystania prawa europejskiego (w tym prawa UE) podczas rekonstrukcji wzorca konstytucyjności pra$\mathrm{wa}^{38}$. Zdaniem TK „Kontrola konstytucyjności wykonywana przez Trybunał wymaga odniesienia do norm Konstytucji jako wzorca, wedle którego ocenia się kontrolowane przepisy prawa. Postulat wykorzystania prawa europejskiego w okresie przedakcesyjnym jako inspiracji interpretacyjnej dla Trybunału Konstytucyjnego oznacza przede wszystkim wykorzystanie tego prawa do rekonstrukcji wzorca konstytucyjnego przy sprawowaniu kontroli. (...) Rekonstruując zatem wzorzec (normę) wedle którego dokonuje się oceny konstytucyjności należy posługiwać się nie tylko samym tekstem Konstytucji, ale - w zakresie w jakim ów tekst odwołuje się do terminów, pojęć i zasad znanych prawu europejskiemu - do tych właśnie znaczeń". Wyrażony wyżej pogląd TK o potrzebie wykorzystania prawa europejskiego także podczas wykładni Konstytucji RP (prounijnej wykładni prawa) nie przeczy zasadzie nadrzędności ustawy zasadniczej w systemie źródeł prawa, natomiast jest przykładem poszanowania zobowiązań międzynarodowych państwa. Podobnie jak nie przeczą tej zasadzie zmiany Konstytucji pod wpływem prawa europejskiego, lecz stanowią przykład europeizacji

${ }^{37}$ Wyrok TK z dnia 28 stycznia 2003 r., K 2/02, OTK-A 2003, nr 1, poz. 4.

${ }^{38}$ S. Biernat, Prawo Unii Europejskiej a Konstytucja RP i prawo polskie - kilka refleksji, „Państwo i Prawo” 2004, z. 11, s. 19. 
ustaw zasadniczych ${ }^{39}$ (jak wspomniano wyżej, to zjawisko znalazło swój wyraz w nowelizacji art. 55 Konstytucji RP).

\section{Wnioski końcowe}

Wśród podstawowych cech prawa UE w orzecznictwie Trybunału Sprawiedliwości UE oraz w doktrynie prawa UE wymienia się: nadrzędność, bezpośredni skutek i bezpośrednią stosowalność. W razie kolizji między prawem UE a prawem krajowym bezwzględne pierwszeństwo należy przyznać temu pierwszemu - niezależnie od rodzaju aktu prawa krajowego (w założeniu dotyczy to także konstytucji państwa członkowskiego). Bezpośredni skutek i bezpośrednie stosowanie prawa unijnego oznacza możliwość powoływania się na to prawo bez konieczności wcześniejszego podejmowania czynności transpozycyjnych zarówno w układzie wertykalnym (jednostka - państwo), jak i horyzontalnym (jednostka - jednostka). Zasadniczo zasady te są akceptowane przez polski Trybunał Konstytucyjny oraz trybunały i sądy innych państw członkowskich. Kwestionowana bywa natomiast zasada nadrzędności prawa UE nad konstytucjami państw członkowskich. Jedynie cypryjska ustawa zasadnicza wprost przewiduje pierwszeństwo prawa unijnego przed jej postanowieniami. W pozostałych przypadkach konstytucje co najwyżej wskazują na pierwszeństwo prawa UE przed ustawodawstwem zwykłym.

Konstytucja RP nie daje podstaw do przyjęcia stanowiska, zgodnie z którym prawo UE ma pierwszeństwo przez ustawą zasadniczą. Kategorycznie brzmiący przepis art. 8 ust. 1 przewiduje, że Konstytucje RP jest najwyższym prawem Rzeczypospolitej Polskiej. Jedynie w stosunku do ustawodawstwa zwykłego (ewentualnie umów międzynarodowych) oraz aktów prawnych niższej rangi znajdujemy w niej przepisy pozwalające przyjąć zasadę nadrzędności prawa unijnego. Nadrzędność Konstytucji RP potwierdza również fakt badania zgodności z ustawą zasadniczą Traktatu Akcesyjnego oraz Traktatów tworzących Unię Europejską. W tym przypadku uznano za wzorzec oceny nie jakiś ponadnarodowy czy międzynarodowy akt, lecz obowiązującą Konstytucję RP.

Akceptacja orzecznictwa Trybunału Sprawiedliwości UE w zakresie zasady nadrzędności również w odniesieniu do Konstytucji RP wymaga zmiany naszej ustawy zasadniczej. Pokazał to już wyrok TK z 27 kwietnia 2005 r. w sprawie europejskiego nakazu aresztowania. Niezbędna jest więc w tym zakresie nowelizacja art. 8 ust. 1 Konstytucji RP oraz jej demokratyczne przyjęcie przez suwerena w drodze referendum ogólnokrajowego.

${ }^{39}$ Zob. M. Ziółkowski, Europeizacja konstytucji - rekonstrukcja znaczenia [w:] Europeizacja konstytucji państw Unii Europejskiej, K. Kubuj, J. Wawrzyniak (red.), Warszawa 2011, s. 21 i n. 
$\mathrm{Z}$ uwagi na doniosłość tej zmiany, zdaniem autora, w celu jej akceptacji należy odwołać się do woli Narodu w drodze referendum ogólnokrajowego.

Zgody na wyzbycie się części atrybutów władzy publicznej i przekazanie ich organizacji międzynarodowej (ponadnarodowej) lub organowi o takim charakterze nie można rozumieć jako całkowitej rezygnacji z suwerenności. Zdaniem autora przyjęcie zasady bezwzględnego pierwszeństwa prawa unijnego przed Konstytucją RP oznacza w praktyce wyzbycie się praktycznie wszystkich atrybutów suwerenności na rzecz UE i stanowi element budowy europejskiego państwa federalnego czy też federalizacji UE. Wyrażane w literaturze stanowisko, zgodnie z którym obecność wielu zasad wypracowanych w praktyce państwa federalnego w UE nie oznacza, że Unia przemieniania się $\mathrm{w}$ państwo federalne $\mathrm{e}^{40}$, $\mathrm{w}$ tym przypadku niewiele zmienia. Zresztą trudno się z tym poglądem zgodzić. Stosowana w tym przypadku retoryka nie zmienia rzeczywistości, jeśli chodzi o charakter i kierunek zmian proponowanych w UE.

\section{Bibliografia}

Arnold R., Tożsamość ponadnarodowa i narodowa w Traktacie z Lizbony [w:] Quo vadis Europo III?, E. Piontek, K. Karasiewicz (red.), Warszawa 2009.

Banaszak B., Konstytucja Rzeczypospolitej Polskiej. Komentarz, Warszawa 2009.

Barcz J., Glosa do wyroku Trybunału Konstytucyjnego z 11.5.2005 r. (zgodność Traktatu akcesyjnego z Konstytucja RP) K 18/04, „Kwartalnik Prawa Publicznego” 2005, nr 4.

Barcz J., Znaczenie idei federalizmu dla procesu integracji europejskiej [w:] J. Barcz, M. Górka, A. Wyrozumska, Instytucje i prawo Unii Europejskiej, Warszawa 2011.

Biernat S., Prawo Unii Europejskiej a prawo państw członkowskich [w:] Prawo Unii Europejskiej. Zagadnienia systemowe, J. Barcz (red.), Warszawa 2003.

Biernat S., Prawo Unii Europejskiej a Konstytucja RP i prawo polskie - kilka refleksji, „Państwo i Prawo” 2004, z. 11.

Biernat S., Glosa do wyroku Trybunału Konstytucyjnego z 11.5.2005 r. (zgodność Traktatu akcesyjnego z Konstytucja RP) K 18/04, „Kwartalnik Prawa Publicznego" 2005, nr 4.

Biernat S., Źródła prawa Unii Europejskiej [w:] Prawo Unii Europejskiej, J. Barcz (red.), Warszawa 2006.

Biernat S., Niedźwiedź M., Prawo międzynarodowe a prawo unijne w świetle Konstytucji [w:] System Prawa Administracyjnego, t. 2, Konstytucyjne podstawy funkcjonowania administracji publicznej, R. Hauser, Z. Niewiadomski, A. Wróbel (red.), Warszawa 2012.

Brodecki Z., Prawo integracji europejskiej, Warszawa 2001.

Doehring K., Völkerrecht, C.F. Müller Verlag, Heidelberg 1999.

${ }^{40} \mathrm{~J}$. Barcz, Znaczenie idei federalizmu dla procesu integracji europejskiej [w:] J. Barcz, M. Górka, A. Wyrozumska, Instytucje i prawo Unii Europejskiej, Warszawa 2011, s. 35-36. 
Garlicki L., Bezpośrednie stosowanie Konstytucji - tezy referatu [w:] Konstytucja RP w praktyce, Warszawa 1999.

Garlicki L., Prawo międzynarodowe i prawo Unii Europejskiej [w:] System Prawa Administracyjnego, t. 2, Konstytucyjne podstawy funkcjonowania administracji publicznej, R. Hauser, Z. Niewiadomski, A. Wróbel (red.), Warszawa 2012.

Garlicki L., Szepietowska B., Miejsce prawa międzynarodowego w systemie źródeł prawa wewnętrznego. Stan obecny i proponowane rozwiązania konstytucyjne, „Biuletyn. Ekspertyzy i Opinie Prawne” 1994, nr 4 (14), Kancelaria Sejmu. Biuro Studiów i Ekspertyz, Warszawa 1995.

Góralczyk W., Sawicki S., Prawo międzynarodowe publiczne, Warszawa 2009.

Koncewicz T.T., Europejska Res Publica [w:] Europa urzędników, Z. Brodecki (red.), Warszawa 2009.

Kowalik-Bańczyk K., Tożsamość narodowa - dopuszczalny wyjątek od zasady prymatu? [w:] Prawo Unii Europejskiej a prawo konstytucyjne państw członkowskich, S. Dudzik, N. Półtorak (red.), Warszawa 2013.

Ibsen K., Völkerrecht, München 1999.

Mikłaszewicz P., Orzecznictwo Trybunału Konstytucyjnego w sprawach zwiazanych z prawem Unii Europejskiej [w:] Europa urzędników, Z. Brodecki (red.), Warszawa 2009.

Muszyński M., Unia Europejska jako reżim zamknięty prawa międzynarodowego [w:] M. Muszyński, D.E. Harnasiuk, M. Kozak, Unia Europejska - instytucje, polityki, prawo, Warszawa 2012.

Ruczkowski P., Zagadnienie bezpośredniego stosowania Konstytucji RP przez organy administracji publicznej i jej miejsce w systemie źródeł prawa [w:] Transformacja polska - oczekiwania i rzeczywistość, J. Dzwończyk, J. Kornaś (red.), „Studia i Prace Uniwersytetu Ekonomicznego w Krakowie" 2010, nr 12.

Ruczkowski P., Źródła prawa administracyjnego [w:] Prawo administracyjne. Część ogólna, ustrojowe prawo administracyjne, wybrane zagadnienia materialnego prawa administracyjnego, M. Zdyb, J. Stelmasiak (red.) Wolters Kluwer, Warszawa 2016.

Sapieżko J., Kardaś S., Polska w Unii Europejskiej [w:] Unia Europejska, t. I, Geneza. System. Prawo, Warszawa 2007.

Seidl-Hohenveldern I., Stein T., Völkerrecht, Berlin-Bon-München 2000, s. 43 i n.; K. Doehring, Völkerrecht, C.F. Müller Verlag, Heidelberg 1999.

Sozański J., Prawo Unii Europejskiej. Analiza krytyczna systemu i doktryny, Toruń 2014.

Tuleja P., Źródła prawa [w:] Prawo konstytucyjne RP, P. Sarnecki (red.), Warszawa 2008.

Tuleja P., Prawo konstytucyjne, Warszawa 1995.

Wentkowska A., Źródła prawa UE [w:] J. Barcik, A. Wentkowska, Prawo Unii Europejskiej z uwzględnieniem Traktatu z Lizbony, Warszawa 2008.

Winczorek P., Konstytucja RP a prawo wspólnotowe, Państwo i Prawo 2004, z. 11.

Wójtowicz K., Suwerenność w procesie integracji europejskiej [w:] Spór o suwerenność, W. Wołpiuk (red.), Warszawa 2001.

Zimmermann J., Prawo administracyjne, Warszawa 2010. 
Ziółkowski M., Europeizacja konstytucji - rekonstrukcja znaczenia [w:] Europeizacja konstytucji państw Unii Europejskiej, K. Kubuj, J. Wawrzyniak (red.), Warszawa 2011.

\section{Akty prawne}

Konwencja wiedeńska o prawie traktatów z dnia 23 maja 1969 r., Dz.U. z 1990 r. Nr 74, poz. 439 - załącznik.

Traktat o przystąpieniu Rzeczypospolitej Polskiej do Unii Europejskiej, podpisany w dniu 16 kwietnia 2003 r. w Atenach, Dz.U. z 2004 r. Nr 90, poz. 864.

Konstytucja Republiki Cypryjskiej, http://biblioteka.sejm.gov.pl/wp-content/ uploads/2015/07/cypr-pol-31052012.pdf.

Konstytucja Rzeczypospolitej Polskiej z dnia 2 kwietnia 1997 r., Dz. U. Nr 78, poz. 483 ze zm.

\section{Orzecznictwo}

Wyrok TS z dnia 2 lutego 1962 r. w sprawie 26/62, NV Algemene Transport - en Expeditie Onderneming van Gend \& Loos v. Nederlandse Administratie der Belastingen, ECR 2001, s. 1.

Wyrok TS z dnia 15 lipca 1964 r. w sprawie 6/64, Flaminio Costa v. E.N.E.L., ECR 1964, s. 585.

Wyrok TS z dnia 17 grudnia 1970 r. w sprawie 11/70, Internationale Handelsgesellachaft GmbH v. Einfuhr und Vorratsstelle für Getreide und Futtermittel, ECR 1970, s. 1125.

Wyrok TS z dnia 9 marca 1978 r. w sprawie 106/77, Amministrazione delle Finanze dello Stato v. Simmenthal SpA, ECR 1978, s. 629.

Opinia TS 1/91 z dnia 14 grudnia 1991 r., ECR 1991, s. I-6079.

Opinia Służby Prawnej Rady z dnia 22 czerwca 2007 r., 11197/07, JUR 260.

Wyrok Federalnego Trybunału Konstytucyjnego z dnia 29 maja 1974 r., Solange-I-Beschluss, BVerfGE 37, 271.

Wyrok Federalnego Trybunału Konstytucyjnego z dnia 22 października 1986 r., Solange II, BVerfGE 73, 339.

Wyrok Federalnego Trybunału Konstytucyjnego z dnia 6 lipca 2000 r., Bananenmarktordnung, BVerfGE 102, 147.

Wyrok Federalnego Trybunału Konstytucyjnego z dnia 12 października 1993 r., Maastricht-Urteil, 2 BvR 2134, 2159/92, BVerfGE 89, 155, http://www.servat. unibe.ch/dfr/bv089155.html.

Wyrok Federalnego Trybunału Konstytucyjnego z dnia 30 czerwca 2009 r., Lisbon-Urteil, 2 BvE 2/08, BVerfGE 123, 267-437, http://www.bundesverfassungsgericht.de/SharedDocs/Entscheidungen/DE/2009/06/es20090630_2bve000208. html.

Wyrok TK z dnia 7 stycznia 1992 r., K 8/91, OTK 1992, cz. 1, s. 84.

Wyrok TK z dnia 1 grudnia 1998 r., K 21/98, OTK 1998, nr 7, poz. 116.

Wyrok TK z dnia 28 stycznia 2003 r., K 2/02, OTK-A 2003, nr 1, poz. 4.

Wyrok TK z dnia 27 kwietnia 2005 r., P 1/05, OTK-A 2005, nr 4, poz. 42.

Wyrok TK z dnia 11 maja 2005 r., K 18/04, OTK-A 2005, nr 5, poz. 49.

Wyrok TK z dnia 24 listopada 2010 r., K 32/09, OTK-A 2010, nr 9, poz. 108.

Uchwała pełnego składu Izby Cywilnej SN z dnia 5 października 1974 r., III CZP 71/73, OSNC 1975, nr 5, poz. 72. 
Streszczenie

Celem niniejszego artykułu jest analiza poglądów Trybunału Konstytucyjnego na temat zasad: pierwszeństwa, bezpośredniego skutku i bezpośredniej stosowalności prawa UE. W szczególności skoncentrowano się w nim na problematyce pierwszeństwa prawa UE przed prawem krajowym. W orzecznictwie i doktrynie prawa UE zasada ta raczej nie jest kwestionowana, natomiast poglądy Trybunału Konstytucyjnego nie są już tak jednoznaczne, zwłaszcza jeśli chodzi o relacje między prawem UE a Konstytucją RP. W tym przypadku mamy do czynienia z pierwszeństwem Konstytucji, przynajmniej jeśli chodzi o podstawowe wolności i prawa jednostki oraz najważniejsze zasady ustrojowe państwa. Trybunał Konstytucyjny to stanowisko wiąże z zasadą suwerenności państwowej.

Słowa kluczowe: zasada nadrzędności prawa Unii Europejskiej, prawo Unii Europejskiej, źródła prawa, hierarchia źródeł prawa, orzecznictwo Trybunału Konstytucyjnego

\section{The Primacy of European Union Law over National Legislation: Notes Exemplified by the Case Law of the Polish Constitutional Court}

Abstract

This article aims at analysing the views of the Constitutional Court as regards the principles of the primacy, direct effect and direct applicability of EU law. It focuses, in particular, on the primacy of EU law over national legislation. In the case law and doctrine of EU law, the principle in question is hardly questioned yet the views of the Constitutional Court are not that unambiguous, particularly in terms of the relations between EU law and the Polish Constitution. In this case, the primacy of the Constitution seems to prevail, at least when it comes to fundamental freedoms and rights of individuals as well as the key principles of the state system. The Constitutional Court links its approach to the principle of state sovereignty.

Keywords: principle of the primacy of European Union law, European Union law, sources of law, hierarchy of sources of law, Constitutional Court case law 